\title{
Transparency and Accountability of Local Government by Internet Financial Reporting in Ex Besuki Residency
}

\author{
Isti Fadah $^{1 *}$, Astri Kurniawati ${ }^{2}$ and Purnamie Titisari ${ }^{3}$ \\ 1,2,3 Faculty of Economics, University of Jember, Jalan Kalimantan 37, Jember, 6812, Jawa Timur, Indonesia
}

\begin{abstract}
Objective - The objective of this research to describe and explore transparency and accountability of local government in Ex Besuki Residency by Internet Financial Reporting and evaluate the implementation of the Law on Public Information Disclosure. Ex Besuki Residency is called an administration area in East Java which consists of local government Banyuwangi, Jember, Bondowoso, and Situbondo in the Dutch East Indies era.

Methodology/Technique - This research is a qualitative non-interactive (non-interactive inquiry) research by using phenomenological approach. This research uses content analysis to analyze Local Government website content appearance related to Internet Financial Reporting. This research uses primary and secondary data. Primary data is in form of observation result in local government website appearance. Secondary data is in form of Internet Financial Reporting obtained by downloading on local government website.

Findings - The results show there is no local government to show its Internet Financial Reporting in full. No publication of most categories of Internet Financial Reporting means reduced accessibility and understanding of Internet Financial Reporting.

Novelty - The paper identifies that accountability and transparency of local governments to the central government through the State Audit Board opinion was not yet able to make local government to be accountable and transparent to the public.
\end{abstract}

Type of Paper: Review

Keywords: Transparency, Accountability, Local Government, Internet Financial Reporting, Public Information Disclosure.

JEL Classification: D82, H83.

\section{Introduction}

Condensed financial information of the Regional Government aims to bring financial accountability and transparency of Local Government. The obligation to carry out the financial information disclosure has been regulated in Law Number 14 of 2008 on Public Information (UU KIP) in force since 2010 and its technical regulated through Information Commission Regulation No. 1 The year 2010 on Public Information Service Standards. The purpose of the provision of financial information is such as to support the disclosure of

\footnotetext{
* Paper Info: Received: January 19, 2017

Accepted: March 10, 2017

* Corresponding author:

E-mail: istitatuk@yahoo.co.id

Affiliation: Faculty of Economics, University of Jember, Indonesia
} 
information to the public and as the evaluation of financial management. Law on Public Information is the starting point of the legality, community efforts to search for, select the source and distribute factual information and reliable (Susanto, 2013).

Law on Public Information guarantees the public's right to information and the government's obligation to provide information. If people are given better access to determine the performance of the body public, and the body of public open itself to be more transparent, as the provisions of the Freedom of Information Law, it is possible the information as one of the factors that can keep the consistency dalampemberantasan corruption committed by public officials, supported by community (Susanto, 2013). Abu-Shanab (2013) research results show that "results indicated resources that the more countries are clean from corruption and publish the budget information, the more e-government projects will prosper and the country will be ready for embracing such phenomenon".

Research on information disclosure has been investigated by Martani, Fitriasari, and Annisa (2013) with the results of 202 of the 429 local government websites are not present or disclose financial information and performance, and only 30 local government (7\%) who preach the Financial Statements, a local government. In addition, Martani et al. (2013) also revealed that in part of the website there is a special menu and/or link to obtain information or documents of financial and performance but a special menu and/or the link does not provide information or documents display as desired. Yogiswara, Noak, and Winaya (2014), Arista (2015), Sofia and Husen (2013), Martani et al. (2013) agreed that financial information is presented on the website of the local government less than non-financial information. Based on these results, this research focuses on Internet Financial Reporting (IFR).

\section{Literature Review}

Agency theory discusses the agency relationship in which one party to delegate certain (principal) to another party who do the job (agent). The relationships formed between local governments and communities cannot be separated from this agency theory. The local government as an agent and society as a principal. Agency theory also suggests that there is a problem of asymmetry of information (information asymmetry) between the agent (the government) that have direct access to information with the principal (society). The existence of information asymmetry is a risk of fraud by the agent. In order to minimize this risk, the local government is obliged to make a statement of responsibility by applying the principles of accountability and transparency as a process of checks and balances.

Accountability has fairly broad meaning in the process of implementation and management of state finances. According to Annex II of Government Regulation No. 71 Year 2010 concerning the Government Accounting Standards, accountability is accountable for resource management and policy implementation is entrusted to entities reporting in achieving the goals set periodically. Regulation of the Audit Board of the Republic of Indonesia No. 01 of 2007 on State Audit Standards mention accountability needed to be able to know the implementation of programs funded with state finance, the level of compliance with the provisions of the legislation in force, as well as to determine the level of effectiveness, efficiency, and effectiveness of the program.

Transparency under Annex I of Government Regulation No. 71 Year 2010 concerning the Government Accounting Standards which provide financial information that is open and honest with the public based on the consideration that the public has a right to find out openly and comprehensively on government accountability in the management of the resources entrusted to him and his obedience to the rule legislation. Kiriteria organization of transparent governance are as follows:

1. The existence of open accountability;

2. The accessibility of financial statements;

3. The existence of the publication of the financial statements, the right to know the results of the audit and the availability of performance information. 
Transparency of information is important to work on improving the public services better. This can all be achieved if public bodies to support greater transparency of the required information (Susanto, 2013).

In accordance with the mandate of Law Number 14 of 2008 on Public Information, public agencies / governments have a website or the official website of the Regional Government. Information Commission Regulation No. 1 Year 2010 on Public Information Service Standards Article 4 point e refers to "... provide the facilities and infrastructure of public information services, including bulletin boards and information desk in every office of the Public Agency, as well as the official website for the State Public Body". Public information shall be made updates / updates periodically, ie no later than do the update once a year at least through the official website and the notice board in a way that is easily accessible to the public in accordance with Article 4 grains g, article 11 paragraph 2 and article 20 paragraph 2 of Commission Regulation No. 1 Year 2010 Information About Standart Public Information Service.

The financial information that must be provided and published periodically by a public entity regulated in Commission Regulation No. 1 Year 2010 Information About Standart Public Information Service article 11 point $\mathrm{d}$ which at least the following:

1. Plan and budget realization report;

2. Balance Sheet;

3. Statement of cash flows and notes to the financial statements prepared in accordance with applicable accounting standards;

4. A list of assets and investments.

\section{Research Methodology}

The purpose of this study was to measure the quality of the content of Internet Financial Reporting in 2014 at the former local government website Kerasidenan Besuki, namely local government Banyuwangi, Jember, Bondowoso, and Situbondo. This study is a non-interactive qualitative research with a phenomenological approach. Using Content analysis method for analyzing the content of Internet Financial Reporting on the local government website. The study was conducted in May 2016. The website address of the local government used are:

Table 1. Local Government Website

\begin{tabular}{|l|l|l|}
\hline No & Local Government & Website Address \\
\hline 1 & Kab. Banyuwangi & http://www.banyuwangikab.go.id \\
\hline 2 & Kab. Jember & http://www.jemberkab.go.id \\
\hline 3 & Kab. Bondowoso & http://www.bondowosokab.go.id \\
\hline 4 & Kab. Situbondo & http://www.situbondokab.go.id \\
\hline Source: Ministry of Interior
\end{tabular}

This study uses primary and secondary data. Primary data obtained from the observation on the website to see the local government. The secondary data in the form of Internet Financial Reporting obtained via download on the website of the local government. Financial Reporting Internet content was measured using the criteria of Information Commission Regulation No. 1 Year 2010 on Public Information Service Standards Article 11-point d. 


\section{Result and Discussions}

\subsection{Research result}

Former local government websites accessible kerasidenan Besuki everything. Home page views to four local governments are different, there is no uniformity layout, symbol, color, and size. Each region tries to show the potential area with free visual design. The absence of a standard look of the website referenced visual design of local government website. Existing guidelines while this only stipulates the information which must be informed and the information is exempt.

Markers / symbol of financial information on the website of the local government realized in the form of text or text indicating the room / place of the financial information presented. Markers / symbol of financial information on the local government website seen on their content "Transparency of Local Budget Management". This is in accordance with the instructions of the Minister of 188.52 / 1797 / SC / 2012 on Transparency of Local Budget Management (TPAD). Based on research on the four only Jember website that does not have content TPAD, while Banyuwangi, Bondowoso, and Situbondo have TPAD content by different names:

Table 2. Name Content Transparency of Local Budget Management

\begin{tabular}{|l|l|}
\hline Local Government & Content Name \\
\hline Kab. Banyuwangi & Local Budget Transparency \\
\hline Kab. Jember & - \\
\hline Kab. Bondowoso & Transparency \\
\hline Kab. Situbondo & Transparency Financial Management \\
\hline
\end{tabular}

TPAD their content does not guarantee the availability of Internet Financial Reporting (IFR) completely. Internet Financial Reporting are to be published according to the Information Commission Regulation No. 1 Year 2010 About Standart Public Information Service article 11 point d which is at least the budget plan, budget realization reports, balance sheets, cash flow statements, notes to financial statements, and a list of assets and investation.

Table 3. Completeness Internet Category Financial Reporting

\begin{tabular}{|l|l|l|l|l|l|}
\hline No & Category IFR 2014 & Banyuwangi & Jember & Bondowoso & Situbondo \\
\hline 1 & Budget Plan & There & None & None & There \\
\hline 2 & Budget Realization Report & There & None & There & There \\
\hline 3 & Balance Sheet & There & None & None & There \\
\hline 4 & Statements of Cash Flows & There & None & None & There \\
\hline 5 & Notes to the Financial Statements & None & None & None & There \\
\hline 6 & A list of assets and investments & None & None & None & None \\
\hline
\end{tabular}

The data presented in Table 3 shows the completeness of the information published by the local government to the public through the website. Banyuwangi local governments presents 4 of 6 category IFR 2014 and presenting Situbondo 5 of 6 category IFR 2014 shall inform the public. While Jember not inform the IFR 2014 and Bondowoso just inform the budget realization reports only. All local governments did not inform the list 
of assets and investments. This is consistent with an overview of the results of the first semester of the Supreme Audit Agency in 2015 that revealed the problem on the local government assets.

Banyuwangi local government has provided five symbols that show the 5 categories IFR 2014, but only four categories of the financial information presented. Symbol Notes to the Financial Statements do not contain information in accordance with the symbol. It supports research Martani et al. (2013) which revealed that in part of the website there is a special menu and / or link to obtain information or documents of financial and performance but a special menu and / or the link does not provide information or documents display as desired.

The absence of a marker / symbol TPAD form of content that does not mean there is no financial information in 2014. The local government did not display the contents TPAD Jember so that IFR 2014 is not visible grain. Through the search engine facility known Jember local government website informs one of six categories, namely category IFR 2014 Budget Plan to address http://jemberkab.go.id/anggaran-pendapatandan-belanja-daerah-kabupaten-jember-tahun-anggaran -2014/.

\subsection{Discussion}

The Ministry of Interior has issued instructions for Interior Minister No.188.52 / 1797 / SC / 2012 on Transparency of Local Budget Management (TPAD) to encourage local organizing budget transparency. The local government comprising former kerasidenan Besuki Banyuwangi, Jember, Bondowoso, Jember and not fully implement those instructions. Jember does not have TPAD content on his website. While the content created on a local government website Banyuwangi, Bondowoso, and Situbondo gave different names by those instructions. Uniformity symbol will be difficult for citizens to access the Internet Financial Reporting. This is not in accordance with article 4 grains g, article 11 paragraph 2 and article 20 paragraph 2 of Commission Regulation No. 1 The year 2010 Information About Standart Public Information Service which confirms the ease of access to the Internet Financial Reporting by the public. In this case the former local government kerasidenan Besuki less transparent in presenting Internet Financial Reporting.

Their content Transparency Budget Management area does not warrant the completeness IFR. Internet Financial Reporting (IFR) local government consists of six categories according to the Information Commission Regulation No. 1 Year 2010 About Standart Public Information Service article 11 point d which is the budget plan, budget realization reports, balance sheets, cash flow statements, notes to financial statements, and a list of assets and investments. There is no local government ex kerasidenan Besuki that meets all these six categories.

Situbondo local government the only one that serves Notes to the Financial Statements at IFR 2014. Notes to Financial Statements an explanation or a detailed list or analysis of the value of an item that is presented in the Budget Realization Statement, Statement of Changes More Budget Balance, Balance Sheet, Statement of Operations, Statement Cash flow and Statement of Changes in Equity. Also included in the Notes to the Financial Statements is the presentation of the information required and recommended by the Government Accounting Standards, and other disclosures necessary for a fair presentation of the financial statements, such as contingent liabilities and other commitments. Each reporting entity is required to present the Notes to the Financial Statements as an integral part of the financial statements for general purposes. Notes to the Financial Statements The financial statements are intended to be understood by the reader broadly, not limited only to certain readers or management of the reporting entity. Financial statements may contain information that may have the potential for misunderstanding among readers. Therefore, in order to avoid misunderstandings, upon presentation of financial statements to be made Notes to Financial Statements containing information to enable users to understand the financial statements.

Based on agency theory, the public is entitled to receive principal accountability report on the mandate given to the government as an agent. No publication of some categories IFR 2014 means local governments reduced the financial information that should be presented, as well as limiting the public to access and understand the accountability of local governments in regional financial management. Transparency and accountability are effective depend on the accountability of public access to the report and a report of findings 
that can be read and understood (Aliyah and Nahar, 2012). Knowing the facts, the accountability and transparency of local government to the community of ex kerasidenan Besuki is still in doubt. Problems asymmetric information occurs in these conditions so we need a management and a good setting for menimalkan asymmetry of information and improve the accountability and transparency of local government to the people.

Accountability and transparency of local governments on financial management to the public is done through publication in places accessible to the public as the website is the Internet Financial Reporting. While the accountability and transparency of local governments to the central government do with the establishment of Local Government Finance Report tested accountability and transparency by the State Audit Board to set out his opinion as a result of the test. The test results in the form of opinions Audit Board consists of four levels, namely unqualified, a qualified, unnatural, and does not give an opinion. The local government Banyuwangi, Bondowoso, and Situbondo obtain unqualified opinion and Jember obtains a qualified opinion on the financial statements 2014. The opinion suggests that local governments be accountable and transparent to the central government. While the results of this study accountability and transparency of local government to the community of ex kerasidenan Besuki is still in doubt. Financial information submitted to the central government and the public should be the same, but in fact not the case. There is a gap accountable and transparent attitude of the local governments to the central government and the public. Accountability and transparency of local governments to the central government through the State Audit Board opinion was not yet able to make local government be accountable and transparent to the public.

\section{Conclusion}

Local Government has provided a symbol of the Internet Financial Reporting, but do not use it with the utmost in informing financial information. Internet Financial Reporting which shall be published composed of the budget plan, budget realization reports, balance sheets, cash flow statements, notes to financial statements, and a list of assets and investments. There is no local government to show its Internet Financial Reporting in full. No publication of most categories of Internet Financial Reporting means reduced accessibility and understanding of Internet Financial Reporting. Without the Notes to the Financial Statements, the value/number found on the Internet financial reporting can be understood less and cause misunderstandings. Opinion Audit Board on Local Government Financial Statements have not been able to encourage local governments to be accountable and transparent in their public financial management to the public.

\section{Reference}

Abu-Shanab, E. A. (2013). The Relationship between Transparency and E-Government: An Empirical Support. EGOV/ePart Ongoing Research, 221, 84-91.

Aliyah \& Nahar (2012). Influence of Regional Financial Statements and accessibility of Regional Financial Statements Against Transparency and Accountability Fiscal Management Jepara district. Auditing and Accounting Journal 8(2) 97-189.

Martani, D., Fitriasari, D., \& Annisa, A. (2013). Transparansi Keuangan Dan Kinerja Pada Website Pemerintah Daerah Kabupaten/Kota Di Indonesia [Finance and Performance Transparency In Government District / city in Indonesia]. Proceeding PESAT (Psikologi, Ekonomi, Sastra, Arsitektur \& Teknik Sipil), 5.

Republic of Indonesia (2010). Information Commission Regulation No. 1 of 2010 About Standart Public Information Service.

Republic of Indonesia (2010). Information Commission Regulation No. 1 of 2010 About Standart Public Information Service.

Republic of Indonesia (2010). Government Regulation No. 71 Year 2010 Concerning the Government Accounting Standards

Republic of Indonesia (2010). Law No. 14 of 2008 on Public Information.

Sofia \& Husen. (2013). Analysis of Local Government Transparency and accountability through the Disclosure On Website. Indonesia Management Journal 12(4) 
Susanto, E. H. (2013). Dinamika Komunikasi Politik dalam Pemilihan Umum [Law Public and government management]. Jurnal Kajian Komunikasi, 1(2).

Yogiswara, P. K., Noak, P. A., \& Winaya, I. K. (2014). Peranan E-Government Dalam Mendukung Transparansi Dan Keterbukaan Informasi Publik [E-Government Role In Supporting Transparency And Public Information Disclosure] (Studi Kasus Website Resmi Pemerintah Kabupaten Klungkung). Citizen Charter, 1(2). 